\title{
INSTRUMENTI ZAŠTITE PROCESNIH PRAVA OBRANE U ISTRAZI PREMA ZAKONU O KAZNENOM POSTUPKU BOSNE I HERCEGOVINE
}

Sažetak: Stupanjem na snagu Zakona o kaznenom postupku Bosne i Hercegovine značajno su izmijenjene uloge tužitelja i suda u odnosu na ranije zakonodavstvo, a osobito u istražnom postupku. Prema postojećem normativnom okviru uloga suda u istrazi je znatno pasivnija jer u ovom stadiju postupka sud ne vrši kontrolu osnovanosti vođenja istrage. Mješoviti akuzatorski koncept istrage kakav egzistira u bosanskohercegovačkom kaznenoprocesnom sustavu doveo je do određenih ograničenja glede prava obrane u istrazi. Istraga je iznimno važan stadij kaznenog postupka jer se u njoj prikupljaju podatci i dokazi potrebni za odlučivanje o podizanju optužnice ili obustavi postupka, kao i dokazi koji se mogu koristiti na glavnoj raspravi i na kojima se može zasnovati presuda. Stoga je nužno osigurati provođenje pravilne $i$ zakonite istrage. To uključuje osiguranje pravičnog $i$ poštenog postupanja prema svim sudionicima $u$ istrazi, osobito obrani. Pravo na obranu temeljno je ljudsko i ustavno pravo zajamčeno i međunarodnim konvencijama. Iz prava na obranu proizlazi nekoliko pojedinačnih prava koja osumnjičenicima pripadaju u prethodnom postupku. Da bi se osigurala djelotvorna sudska zaštita prava osumnjičenika, radom se analizira bosanskohercegovački kaznenoprocesni sustav uz prikaz poredbenopravnih rješenja glede zaštite postupovnih prava obrane u istrazi. Temeljni je problem pri analizi bosanskohercegovačkog normativnog okvira nepostojanje djelotvorne sudske zaštite procesnih prava obrane, kao i nepostojanje djelotvornog pravnog lijeka na provođenje istrage koji bi obrani omogućio ostvarenje načela pravičnog suđenja te načela jednakosti oružja u prethodnom postupku. Osim toga, radom se analizira i pitanje upoznavanja osumnjičenika $s$ donošenjem naredbe o provođenju istrage jer prema važećim propisima osumnjičenik i ne mora znati da se protiv njega vodi istraga čime se narušava načelo pravičnog suđenja.

Ključne riječi: $\quad$ prava obrane $u$ istrazi, naredba o pokretanju istrage, instrumenti zaštite postupovnih prava obrane, djelotvoran pravni lijek, sudska kontrola nad provodenjem istrage

\footnotetext{
* Dr. sc. Maja Pilić, naslovna docentica Pravnog fakulteta Sveučilišta u Mostaru, Matice hrvatske b.b., 88000 Mostar, Bosna i Hercegovina. E-adresa: maja.pilic@pf.sum.ba. ORCID: https://orcid.org/0000-0003-1979-3023.

** Zdravko Rajić, odvjetnik, Stjepana Radića 7, 88000 Mostar, Bosna i Hercegovina. E-adresa: zdravko.rajic1@tel.net.ba. ORCID: https://orcid.org/0000-0003-2638-8974.
} 


\section{UVOD}

Bosna i Hercegovina (dalje u tekstu: $\mathrm{BiH}$ ) u svome povijesnom razvoju kaznenog procesnog prava prošla je nekoliko etapa. Prvu etapu u tom razvoju obilježio je raspad bivše države te nasljeđivanje njezinih pravnih propisa. ${ }^{1}$ Nakon toga uslijedila je etapa potpisivanja Daytonskog mirovnog sporazuma u studenom 1995. godine koju je obilježilo donošenje entitetskih kaznenih i kaznenih procesnih zakona krajem 1998. godine. Treće razdoblje je obilježilo donošenje sadašnjeg Zakona o kaznenom postupku $\mathrm{BiH}^{2}$ koji je doživio više reformskih izmjena i dopuna. Upravo je razvoj kaznenog procesnog prava u $\mathrm{BiH}$ uvjetovao usvajanje mješovitog modela kaznenog postupanja, osobito zbog promjena koje su se dogodile u vezi s provođenjem istrage. Prema ranijem zakonodavstvu istraga je bila u nadležnosti suda, točnije, njome je rukovodio istražni sudac koji je bio ovlašten ispitati osumnjičenika. ${ }^{3}$ Prema sadašnjim rješenjima sud ne mora ni znati, kao ni osumnjičenik, da se provodi istraga sve dok tužitelj ne odluči ispitati osumnjičenika, odnosno dok ne mora provesti neku dokaznu radnju za koju je potrebno sudsko odobrenje.

Istraga je prethodni stadij kaznenog postupka koji obuhvaća skup svih radnji i mjera koje poduzima tužitelj ili ovlaštene službene osobe uvijek kada postoje osnove sumnje da je počinjeno kazneno djelo, s primarnim ciljem podizanja optužnice protiv osumnjičenika ili pak odustajanja od kaznenog progona, ${ }^{4}$ kao i s ciljem prikupljanja svih dokaza, osobito dokaza koji se mogu koristiti na glavnoj raspravi i na kojima se može zasnovati presuda. ${ }^{5}$ Stoga je zadaća istrage dvojaka. S jedne strane cilj je otkrivanje kaznenog djela i njegova počinitelja, dok $s$ druge strane istraga treba osigurati načelo pretpostavke nedužnosti osumnjičenika. Isključiva nadležnost za provođenje istrage dana je tužitelju. O pokretanju istrage tužitelj odlučuje samostalno u obliku naredbe za provođenje istrage uvijek kada postoje osnove sumnje ${ }^{6}$ da je počinjeno kazneno djelo. Dakle, osnove sumnje preduvjet su za provođenje istrage za razliku od ranije zahtijevane osnovane sumnje. ${ }^{7}$ Tako su relativizirana prava obrane u istrazi što dovodi u pitanje ostvarenje temeljnog načela kaznenog postupka - prava na pravično suđenje. Premda je krajnji cilj svakog društva očuvanje njegove sigurnosti i sprječavanje svih oblika kriminaliteta, arbitrarno pokretanje istraga na temelju osnova sumnje kao niskog stupnja vjerojatnosti o počinjenju kaznenog djela ne doprinosi tome cilju. Osim toga, izmjenama zakona o kaznenom postupku različito se regulira pitanje instrumenata zaštite prava osumnjičenika $\mathrm{u}$ istrazi, odnosno njihovih branitelja. Stoga je cilj ovog rada ukazati na postojeći zakonodavni okvir glede zaštite procesnih prava obrane u istrazi te pronalaženje de lege ferenda prijedloga za kaznenoprocesno zakonodavstvo $\mathrm{BiH}$ oslanjajući se na poredbenopravna rješenja.

1 Zakon o krivičnom postupku, Službeni list SFRJ, (SL 4/1977, 36/1977, 14/1985, 26/1986, 74/1987, 57/1989, 3/1990). Dalje u tekstu: ZKP SFRJ.

2 Zakon o kaznenom postupku Bosne i Hercegovine, (SG BiH 3/2003, 32/2003, 36/2003, 26/2004, 63/2004, 13/2005, 48/2005, 46/2006, 29/2007, 53/2007, 58/2008, 12/2009, 16/2009, 53/2009, 93/2009, 72/2013, 65/2018) (dalje u tekstu: ZKP BiH).

3 Članak 150. st. 2. ZKP-a SFRJ.

4 Hajrija Sijerčić Čolić, Krivično procesno pravo, Knjiga II, Tok redovnog krivičnog postupka i posebni postupci, (4th ed, Pravni fakultet Univerziteta u Sarajevu 2017) 28.

5 Tako: Presuda Vrhovnog suda Federacije Bosne i Hercegovine broj 030 K 00792412 Kž 8 VSFBiH (22. svibnja 2013.).

6 Osnove sumnje su prema sudskoj praksi najniža razina vjerojatnosti; Vidjeti: Željko Karas, 'Sudska praksa o policijskom postupanju: osnove sumnje i osnovana sumnja, zatvoreni krug indicija' (2011) 20(4) Policija i sigurnost 617-618.

7 Članak 148. ZKP-a SFRJ; Osnovana sumnja je viši stupanj sumnje zasnovan na prikupljenim dokazima koji upućuju na zaključak da je počinjeno kazneno djelo, čl. 20. t. ZKP-a BiH. 


\section{PRAVA OSUMNJIČENIKA U ISTRAZI}

Prava osumnjičenika u istrazi uređena su odredbama čl. 6., 7. i 78. ZKP-a BiH. Temeljno i najvažnije pravo osumnjičenika $u$ istrazi pravo je na obranu zajamčeno zakonima i međunarodnim pravom. ${ }^{8} \mathrm{O}$ pravu na obranu govorili su brojni teoretičari i praktičari, osobito o važnosti zaštite ovog prava u prethodnom postupku. Međutim, promatrajući prava obrane $\mathrm{u}$ istrazi prema $\mathrm{ZKP}-\mathrm{u} \mathrm{BiH}$ javljaju se određene kontradiktornosti zakonopisca u reguliranju položaja obrane u odnosu na drugu stranku postupka. To je rezultat postojanja mješovitog akuzatorsko-inkvizitorskog tipa kaznenog postupka u kojem je položaj osumnjičenika i njegova branitelja u istrazi ograničen, dok su mu s druge strane iz akuzatorskog modela dodijeljena određena procesna prava u istrazi, ali tako ograničena da osumnjičenik u istrazi ne uživa ravnopravnost kakva mu pripada po konvencijskom pravu. ${ }^{9}$ Pravo na obranu u istrazi, kao i u kasnijem kaznenom postupku, obuhvaća nekoliko pojedinačnih prava koja osumnjičenicima osiguravaju jednakost u postupku. Prema $\mathrm{ZKP}-\mathrm{u} \mathrm{BiH}^{10}$ to su sljedeća prava:

- $\quad$ - pravo na obavijest o djelu

- $\quad$ - pravo na izjašnjenje o svim činjenicama i dokazima in peius i in favorem

- - pravo na šutnju

- $\quad$ - pravo na branitelja

- $\quad$ - pravo na vrijeme za pripremu obrane

- $\quad$ pravo na razmatranje spisa predmeta. ${ }^{11}$

\subsection{PRAVO NA OBAVIJEST O DJELU}

Pravo na obavijest o djelu obuhvaća pravo osumnjičenika da prije ispitivanja bude obaviješten o djelu koje mu se stavlja na teret, o osnovama sumnje protiv njega, kao i obavijest da se njegov iskaz može kasnije koristiti kao dokaz u postupku. Prema sudskoj judikaturi Europskog suda za ljudska prava (dalje u tekstu: ESLJP) riječ je o jamstvima koja odražavaju pojam pravičnog suđenja premda im je inherentni cilj uvijek da osiguraju ili doprinesu osiguranju pravičnosti kaznenog postupka kao cjeline. Obavijest o djelu sadrži obavijest o činjeničnom i zakonskom opisu onoga što se osumnjičeniku stavlja na teret, s naglaskom da ta obavijest treba biti u pisanu obliku što zakon izričito ne navodi. Obavijest o osnovama sumnje obavijest je o činjenicama i dokazima na kojima se zasniva sumnja da je osoba počinila djelo koje joj se stavlja na teret. Također, Zakon propisuje i obvezu da se osumnjičenog upozori da se njegov iskaz dan u istrazi može kasnije koristiti kao dokaz u kaznenom postupku. ${ }^{12}$ Pružanje ovih obavijesti obveza je onoga tko

8 Pravo na obranu proizlazi iz čl. 14. Međunarodnog pakta o građanskim i političkim pravima, čl. 11. st. 1. Opće deklaracije o ljudskim pravima, čl. 6. st. 3. (Europske) Konvencije za zaštitu ljudskih prava i temeljnih sloboda.

9 Načelo ravnopravnosti stranaka ili jednakost oružja znači da svaka strana u postupku ima iste mogućnosti i pravo iznijeti svoje argumente, odnosno dobiti informacije o činjenicama i navodima druge strane, kao i očitovati se na njih. Tako: Hajrija Sijerčić Čolić (n 4) 117.

11 Članak 47. ZKP-a BiH. 
obavlja ispitivanje i te se obavijesti moraju dati prije početka ispitivanja, kao i zabilježiti u zapisnik o ispitivanju. Isto tako, Zakon propisuje da se ove obavijesti moraju dati "već na prvom ispitivanju"13 što znači da osumnjičenik mora obavijest o djelu dobiti u najkraćem roku. Međutim, postavlja se pitanje poštuje li se ovo pravo na obavještenje u najkraćem roku ako je osumnjičenik prvi put ispitan tek na kraju istrage. Naime, prema ranijoj formulaciji čl. 225. st. 2. ZKP-a BiH ekstenzivno je bila postavljena odredba o mogućnosti ispitivanja osumnjičenog do kraja istrage. Izmjenom $\mathrm{ZKP}-\mathrm{a} \mathrm{BiH}^{14}$ predviđeno je da se optužnica ne može podignuti ako osumnjičeni nije ispitan, ${ }^{15}$ čime zakonodavac i dalje nije restriktivno odredio kad osumnjičenik mora biti ispitan, a time i upoznat s naredbom o provođenju istrage. Mogućnost ispitivanja osumnjičenog na kraju istrage trebala bi biti iznimna i to u slučajevima ako bi se time ugrozili ciljevi istrage. Suprotno postupanje tužitelja može se uzeti kao nepravilno jer se njime dovodi u pitanje ostvarivanje prava na pravično suđenje. Međutim, tumačenjem odredbe čl. 225. st. 6. ZKP-a BiH i dalje proizlazi da tužitelj nema obvezu saslušanja osumnjičenog odmah po donošenju naredbe o provođenju istrage, već tu mogućnost ima sve do samog okončanja istrage. Ovakvo zakonsko rješenje otvara pitanje kada osumnjičenik treba biti upoznat $\mathrm{s}$ time da se protiv njega vodi istraga. Autori Komentara ZKP-a BiH smatraju da bez obzira na to kad će tužitelj saslušati osumnjičenog, on treba upoznati osumnjičenog s donošenjem naredbe o provođenju istrage u što kraćem roku od trenutka donošenja naredbe. Tako se eliminira mogućnost kršenja prava osumnjičenog u smislu prava na pripremu obrane i aktivnog sudjelovanja u postupku, a što bi mogao biti slučaj kad osumnjičenik ne bi znao da se protiv njega vodi istraga sve do samog okončanja istrage. ${ }^{16} \mathrm{Na}$ važnost upoznavanja osumnjičenika s naredbom o pokretanju istrage ukazuje i činjenica da istrage znaju trajati više od pet godina, ${ }^{17}$ pa bi osumnjičenik pravovremenim obavještenjem o pokretanju istrage protiv njega mogao pripremati obranu i već u ovom prethodnom postupku dokazivati svoju nevinost. U odnosu na trajanje kaznenih istraga, zakonodavac je propisao rokove u kojima istraga treba biti okončana te da ako se istraga ne okonča u propisanim rokovima, a postoje procesne pretpostavke, smatrat će se da je obustavljena, o čemu tužitelj u formi naredbe obavještava osumnjičenika, glavnog tužitelja i oštećenika. ${ }^{18}$ Međutim, upoznavanjem osumnjičenika s naredbom o obustavi istrage ne ostvaruje se njegova jednakopravnost $\mathrm{u}$ istrazi samim time što on nema mogućnost osporavanja činjenica i dokaza koji mu se stavljaju na teret još puno prije, na početku istrage. Zakon također propisuje u odredbama o obustavi istrage da će naredbu o obustavi istrage dostaviti osumnjičeniku ako je ispitan. ${ }^{19}$ To znači da ako osumnjičenik u istrazi nije ispitan, a tužitelj utvrdi da ne postoje okolnosti za kazneni progon istog, istragu će obustaviti bez upoznavanja osumnjičenog da je uopće bio u tom statusu. Takvo prikriveno zadiranje u prava pojedinaca bez njihova znanja, osobito kad nema smetnji da budu s time upoznati (ako se time ne bi ugrozili ciljevi istrage) nije u skladu s postulatima na kojima počiva kazneno procesno pravo. Upoznavanje osumnjičenika s pokretanjem istrage doprinijelo bi osiguranju prava na pravično suđenje, jednakosti oružja u prethodnom postupku, otkrivanju kaznenih događaja

13 Članak 6. st. 1. ZKP-a BiH.

14 Službeni glasnik BiH, broj 65/2018 od 21. rujna 2018.

15 Članak 225. st. 6. ZKP-a BiH.

16 Hajrija Sijerčić Čolić i drugi, Komentari zakona o krivičnom/kaznenom postupku u Bosni i Hercegovini, (Zajednički projekat Vijeća Evrope i Evropske komisije, Sarajevo, 2005) 54-55, 606-607.

17 Sudska praksa br. S1 2 K 00255210 Krn (X-KRN/09/707).

18 Članak 225. st. 5. ZKP-a BiH. 
u ovoj ranoj fazi, ali i osiguranje načela presumpcije nevinosti. Dakle, analizom postojećeg normativnog kaznenoprocesnog sustava vidljivo je kako je zakonodavac popisao obvezu tužitelja o obavijesti osumnjičenog o nemogućnosti okončanja istrage ${ }^{20}$ te o obustavi istrage, ${ }^{21}$ ali ne propisuje obvezu obavijesti o donošenju naredbe o provođenju istrage. Osim toga, postoji stajalište bosanskohercegovačke stručne javnosti koje osiguranje prava na obavijest o djelu i osnovama sumnje protiv osumnjičenog tumače dostavljanjem poziva osumnjičenom na prvo ispitivanje $u$ slučajevima kada prema osumnjičenom nije poduzeta nijedna istražna mjera i radnja koja zahtijeva sudsko odobrenje. Autori ovog stajališta navode kako je ovo pravo pozivom ograničeno jer se pri pozivanju osumnjičenom ne priopćava koje osnove sumnje stoje protiv njega, niti činjenični opis kaznenog djela koje mu se stavlja na teret, nego se osumnjičenom u pozivu samo naglašava naziv kaznenog djela, odnosno njegova pravna kvalifikacija. ${ }^{22} \mathrm{O}$ pitanju kada osumnjičenik treba biti upoznat s ovim pravom Ustavni sud $\mathrm{BiH}$ navodi da "time što čl. 6. EKLJP zahtijeva da apelant bude u najkraćem roku obaviješten o optužbi koja se podiže protiv njega, ne znači da o tome mora biti obaviješten u nalogu za uhićenje, već u najkraćem roku." ${ }^{23}$ U svakom slučaju povreda ovog prava značila bi postojanje razloga isključenja kaznenog progona jer $\mathrm{ZKP} \mathrm{BiH}$ ne propisuje mogućnost podizanja optužnice bez ispitivanja osumnjičenika. ${ }^{24}$

Za razliku od bosanskohercegovačkog pravnog okvira, Zakon o kaznenom postupku Republike Hrvatske, ${ }^{25}$ osim što za provođenje istrage zahtijeva postojanje osnovane sumnje da je počinjeno kazneno djelo, također propisuje da se rješenje o provođenju istrage dostavlja osumnjičeniku u roku od osam dana od donošenja zajedno s poukom o pravima. ${ }^{26} \mathrm{U}$ rješenju o provođenju istrage navode se i hitne dokazne radnje koje su provedene prije donošenja rješenja, kao i to koje okolnosti državni odvjetnik namjerava istražiti i koje dokazne radnje provesti. ${ }^{27}$ Protiv rješenja o provođenju istrage okrivljenik ima pravo žalbe sucu istrage u roku od osam dana od dana primitka rješenja. Žalba se podnosi državnom odvjetniku koji ju je dužan odmah, zajedno sa spisom predmeta, dostaviti sucu istrage. ${ }^{28} \mathrm{U}$ slučajevima kada se provodi istraživanje, državni odvjetnik dužan je u roku od tri dana otkad je proveo prvu dokaznu radnju obavijestiti osumnjičenika. ${ }^{29}$ Međutim, za razliku od ZKP-a BiH, ZKP RH propisuje i ograničenje prava na obavijest o optužbi zbog razloga propisanih čl. 218.a ZKP-a RH, odnosno situacije kad se dostava rješenja o provođenju istrage može odgoditi najviše za trideset dana i to u slučaju ako bi se dostavom rješenja o provođenju istrage ugrozio život ili tijelo osobe ili imovina velikih razmjera ako se istraga provodi za kaznena djela protiv $\mathrm{RH}$, protiv oružanih snaga RH za koja je propisana kazna zatvora teža od pet godina, kaznena djela vezana uz

20 Članak 225. st. 3. ZKP-a BiH.

21 Članak 225. st. 5. ZKP-a BiH.

22 Milan Tegeltija Krivična oblast: istražni postupak, Modul 1 (Visoko sudsko i tužilačko vijeće Bosne i Hercegovine 2006) 48, <https://www.pravosudje .ba/vstv/faces/docservlet?p_id_doc=346> pristupljeno 27. srpnja 2019.

23 Odluka o meritumu br. AP 86/05 (SG BiH br. 17/2006) u Pregled praske Ustavnog suda BiH (2nd ed, Sarajevo, 2016) 100. Vidjeti Presudu vijeća Apelacijskog odjeljenja br. S1 2 K 00335414 Kž 13 od 19. rujna 2014., Bilten sudske prakse br. 5/2015, 85-86. 70/2017, 126/2019, 126/2019) (dalje u tekstu: ZKP RH). 
terorizam, pripremanje kaznenih djela protiv vrijednosti zaštićenih međunarodnim pravom te kaznenih djela zločinačkog udruženja. Jednako kao ZKP BiH, i ZKP RH propisuje rokove u kojima se istraga mora završiti, ali ne predviđa sankcije u slučaju prekoračenja tih rokova. ${ }^{30}$

2.2.

\section{PRAVO OSUMNJIČENIKA NA IZJAŠNJENJE O ČINJENICAMA I DOKAZIMA IN PEIUS I IN FAVOREM}

Ovo pravo podrazumijeva mogućnost da se osumnjičenik izjasni o svim činjenicama i dokazima koji ga terete (in peius) i da iznese sve činjenice i dokaze koji mu idu u korist (in favorem). Pravo da se izjasni o svim činjenicama i dokazima omogućava osumnjičeniku osiguranje jednakosti stranaka u prethodnom postupku. O ovom pravu osumnjičenik se mora obavijestiti, kako pri prvom ispitivanju, tako i pri svakom idućem ispitivanju. Dakle, ono egzistira tijekom cijelog kaznenog postupka pa tako i u istrazi. ${ }^{31}$ Međutim, postavlja se pitanje kako će osumnjičenik ostvariti ovo pravo na izjašnjenje u situacijama kada je protiv njega pokrenuta istraga, a on još nije ispitan? S obzirom na to da prema postojećim zakonskim rješenjima osumnjičenik ne mora ni znati da se protiv njega vodi istraga, on ovo pravo može ostvarivati samo kada bude ispitan, a to može biti i na kraju istrage. Kad bi osumnjičeniku bila dostavljena naredba (rješenje) o provođenju istrage, on bi u žalbi na tu naredbu eventualno mogao istaknuti sve činjenice i dokaze koji mu idu u korist. Tako bi bilo osigurano ovo minimalno pravo osumnjičenika u istrazi, ali i sudska kontrola samog istražnog postupka. Osim toga, ovo pravo je u koliziji s pravom na razmatranje spisa predmeta u istrazi, gdje je zakonodavac suzio vrstu dokaznog materijala koji osumnjičenik, odnosno njegov branitelj može razmatrati. Tako će ovo pravo biti ograničeno $u$ istrazi samim time što osumnjičenik $u$ istrazi ima pravo razmatrati samo onaj dio spisa koji mu ide u korist. ${ }^{32}$ Treba naglasiti kako sudska praksa potvrđuje da povreda ovog prava može dovesti do povrede prava na pravično suđenje. ${ }^{33}$

\subsection{PRAVO NA ŠUTNJU}

Pravom na šutnju osumnjičenik u istrazi ostvaruje svoju pasivnu ulogu u smislu da nije dužan iznijeti svoju obranu ni odgovarati na postavljena pitanja. Ovo pravo osumnjičenika jedno je od najznačajnijih u ostvarivanju prava na obranu. Policijska tijela moraju ovu pouku dati odmah nakon što je osumnjičena osoba lišena slobode. U tijeku kaznenog postupka ovom obvezom je vezan tužitelj, ${ }^{34}$ sudac za prethodno saslušanje kad uzima izjavu o kriv-

30 Vidjeti: Ante Novokmet i Zoran Sršen 'Neučinkoviti kazneni postupak pred sudovima - implementacija presuda Europskog suda za ljudska prava' (2017) 24(2), Hrvatski ljetopis za kaznene znanosti i praksu, 293-334. 
nji, ${ }^{35}$ sudac, odnosno predsjednik vijeća kad daje pouke optuženom. ${ }^{36}$ Ako je došlo do povrede prava na šutnju u smislu davanja pouke o pravu na šutnju, na takvom iskazu osumnjičenika se ne može zasnovati sudska odluka. ${ }^{37}$ Pouka o pravu na šutnju mora biti dana izričito, kako bi osumnjičenik slobodno odlučio hoće li dati iskaz ili će iskoristiti navedeno pravo. Ovo pravo se označava kao pravo na šutnju ili privilegij od samooptuživanja, a koje podrazumijeva da svatko kome se stavlja na teret počinjenje kaznenog djela ima pravo ne svjedočiti protiv sebe i ne priznati krivnju. ${ }^{38}$ Kad je riječ o sudskoj praksi, ESLJP je o pravu na šutnju odlučivao kroz načelo pravičnog postupka. Poznati primjeri iz judikature ESLJP-a Saunders protiv Velike Britanije $e^{39} i$ Heaney and McGuinness protiv Irske $e^{40}$ potvrdili su obvezu poštovanja prava na šutnju. Ono je potvrđeno i u nekim kasnijim predmetima poput Gäfgen protiv Njemačke. ${ }^{41}$ Pravo na šutnju osobito pretpostavlja da tužiteljstvo optužbu protiv osumnjičenika nastoji dokazati bez iznude priznanja od osumnjičenika primjenom sile i drugih nedopuštenih postupaka te protiv volje osumnjičenika, naročito zbog toga što se na takvim iskazima ne može zasnovati sudska odluka (čl. 10., čl. 77. st. 2. i 3. ZKP-a BiH).

\subsection{PRAVO NA BRANITELJA}

Pravo na branitelja ${ }^{42}$ temeljno je pravo osumnjičenika u istrazi. Kako navodi Valković "obrana je jamstvo pravilnosti rada pravosuđa, a pravilnost rada pravosuđa nije samo zahtjev okrivljenika nego zahtjev uređenog i demokratskog društva". ${ }^{43}$ Pravo na branitelja svoj temelj nalazi u čl. 6. st. 3. EKLJP-a, kao i čl. 14. st. 3. MPGPP-a. Osim toga, čl. 6. st. 3. t. c) EKLJP-a zahtijeva da pravna pomoć osumnjičenom bude besplatna, ako on nema dovoljno sredstava da je plati i kada interesi pravde to zahtijevaju. Ovo pravo rezultat je zahtjeva postavljenih u predmetu Salduz protiv Turske. ${ }^{44}$ Salduz doktrina ${ }^{45}$ ne znači da osumnjičenik mora imati branitelja tijekom prvog ispitivanja, nego da osumnjičenik mora imati pravo pristupa branitelju, ali se tog prava može odreći. Odricanje od prava na branitelja imat će učinak samo ako je dano

35 Članak 229. st. 1. ZKP-a BiH.

36 Članak 259. ZKP-a BiH.

37 Članak 78. st. 6. ZKP-a BiH.

38 Vidjeti čl. 14. st. 3. MPGPP-a.

39 Saunders $v$ United Kingdom App no 19187/91 (ECtHR, 17 December 1996).

40 Heaney and Mcguinness v Ireland App no 34720/97 (ECtHR, 21 December 2000).

41 Gäfgen protiv Njemačke od 1. lipnja 2010.

42 U Njemačkoj za branitelja se mogu izabrati odvjetnici i profesori prava na njemačkim sveučilištima u skladu s Okvirnim zakonom o visokom obrazovanju, koji su kvalificirani za suce. § 138 njemačkog Zakona o kaznenom postupku.

43 Laura Valković, 'Pravo na branitelja u praksi nacionalnih sudova i praksi Europskog suda za ljudska prava (pregled novijih odluka)' (2019) Zbornik radova Novine u kaznenom zakonodavstvu 97.

44 Salduz protiv Turske od 27. studenog 2008 “(...) pristup branitelju mora biti osiguran od prvog ispitivanja osumnjičenika od policije, osim ako bi se u svjetlu posebnih okolnosti svakog slučaja pokazalo da postoje prinudni razlozi za ograničavanje tog prava."

45 Vidjeti Mađer protiv Hrvatske od 21. lipnja 2011. O tome i: Laura Valković i Zoran Burić, 'Primjena izabranih elemenata prava na formalnu obranu iz prakse Europskog suda za ljudska prava u hrvatskom kaznenom postupku' (2011) 18(2) Hrvatski ljetopis za kazneno pravo i praksu 521-530; Elizabeta Ivičević Karas, 'Pomicanje granica prava na branitelja pod utjecajem europskog kaznenog prava' (2015) 22(2) Hrvatski ljetopis za kazneno pravo i praksu 355-382. 
na nedvojben način, ako nije protivno javnom interesu te mora biti popraćeno minimalnim jamstvima razmjernima važnosti odricanja. ${ }^{46}$ Odricanje mora biti dano izričito, dakle ne bi se smjelo dopustiti konkludentno odricanje od prava na izbor branitelja jer bi se tako relativiziralo samo pravo obrane što vodi pravnoj nesigurnosti daljnjeg kaznenog postupka. Osim toga, ESLJP je u presudama poslije Salduza jasno naznačio da uhićenik ima pravo na branitelja već od trenutka uhićenja, a ne samo od trenutka prvog policijskog ispitivanja. O tome govori i Direktiva o pravu na branitelja u kaznenom postupku iz 2013. godine ${ }^{47}$ propisujući obvezu država članica da pravo na branitelja zajamče svakom osumnjičeniku, ne samo od trenutka oduzimanja slobode, nego i pri svakom ispitivanju od strane tijela kaznenog postupka, uključujući ispitivanje od strane policije (čl. 3. st. 2. t. c) Direktive iz 2013.). ${ }^{48}$

Kad je riječ o praksi ESLJP-a, poznata su dva predmeta u kojima je Republika Hrvatska osuđena za povredu članka 6. st. 3. t. c) EKLJP-a, zato što uhićeniku nije bilo omogućeno da se tijekom policijskog ispitivanja brani uz pomoć branitelja. To su predmeti Mađer i Šebalj. ${ }^{49} \mathrm{U}$ predmetu Dvorski protiv Hrvatske, ESLJP je presudio da se osumnjičeniku treba osigurati pravo na branitelja od početnih faza, dakle od prethodnog postupka. Osim o pravu na branitelja prema vlastitu izboru, ESLJP je u ovom predmetu također utvrđivao je li izostanak ovog prava utjecao na osumnjičenika u smislu da je djelujući pod prisilom inkriminirao samog sebe. ${ }^{50}$ Međutim, ograničenje ovog prava vidimo još u presudi Salduz gdje je ESLJP istaknuo da pravo na branitelja može biti ograničeno samo iznimno, ako za to postoje valjani i dostatni razlozi. O tim razlozima ESLJP je prvi put nakon predmeta Salduz odlučivao u predmetu Ibrahim i drugi protiv Ujedinjenog Kraljevstva ${ }^{51}$ navodeći da je ograničenje prava na branitelja dopustivo "samo u iznimnim okolnostima te samo privremeno, a odluka o ograničenju mora biti utemeljena na individualnoj procjeni specifičnih okolnosti konkretnog slučaja te mora biti u skladu s domaćim pravom". ${ }^{52}$

\subsection{PRAVO NA ODGOVARAJUĆE VRIJEME I MOGUĆNOST ZA PRIPREMU OBRANE}

Osumnjičeniku u istrazi mora se osigurati dovoljno vremena i mogućnosti za pripremu obrane. ${ }^{53}$ Ovo pravo također je odraz načela jednakosti oružja stranaka u postupku. Pri ocjeni

46 ESLJP u domaćem predmetu Smajić protiv Bosne i Hercegovine od 16. siječnja 2018. podsjeća da "ni slovo, ni duh čl. 6. EKLJP-a ne sprječava osobu da se vlastitom slobodnom voljom odrekne, izričito ili prešutno, prava na garancije pravičnog suđenja. Međutim, takvo odricanje, da bi bilo valjano u smislu EKLJP-a, mora biti nedvosmisleno utvrđeno, ne smije ići protiv bilo kojeg važnog javnog interesa i mora biti popraćeno minimalnim garancijama srazmjerno njegovom značaju." O tome usp. Laura Valković, 'Procesna prava obrane prema V. Noveli Zakona o kaznenom postupku' (2013) 20/2 Hrvatski ljetopis za kazneno pravo i praksu, 531.

47 Direktiva 2013/48/EU Europskog parlamenta i Vijeća od 22. listopada 2013. o pravu na pristup odvjetniku u kaznenom postupku i u postupku na temelju europskog uhidbenog naloga te o pravu na obavješćivanje treće strane u slučaju oduzimanja slobode i na komunikaciju s trećim osobama i konzularnim tijelima, SL 294/1, 6. studenoga 2013. (dalje u tekstu: Direktiva 2013/48/EU).

48 Ćamil Salahović i Davor Bubalo, 'Pravo na obranu prema Zakonu o kaznenom postupku Republike Hrvatske' (2016) 9(17) Anali Pravnog Fakulteta Univerziteta u Zenici 233-234.

49 Vidjeti o ovim predmetima u: Laura Valković, Procesna prava obrane..., (n 45) 532.

50 Dvorski protiv Hrvatske od 20. listopada 2015. O tome vidjeti u: Laura Valković, 'Pravo na pristup branitelju u svjetlu presude Dvorski protiv Hrvatske' (2016) 23(2) Hrvatski ljetopis za kaznene znanosti i praksu 339-369.

51 Ibrahim i drugi protiv Ujedinjenog Kraljevstva od 13. rujna 2016. O predmetu vidjeti u: Laura Valković, Pravo na branitelja..., (n 50), 99-100.

52 Ibid.

53 Pravo pripreme obrane usko je povezano s pravom na obavijest o djelu, a samim time i pravu na branitelja.; Marin Mrčela, Dražen Tripalo i Laura Valković, 'Odabrana poglavlja o ljudskim pravima i temeljnim slobodama-kaznenopravni aspekt' 
o povredi prava na odgovarajuće vrijeme potrebno za pripremu obrane i realnih mogućnosti te pripreme faktično je pitanje, pri kojem se osobito uzima u obzir stupanj osumnjičenikove odgovornosti za nedostatak vremena za pripremu, kao i druge okolnosti poput činjenične i pravne složenosti slučaja, stadiju postupka, o tome brani li se okrivljenik sam ili uz pomoć branitelja, o opterećenosti branitelja i dr. Neke od poznatijih odluka ESLJP-a o pravu na pripremu obrane jesu: Twalib protiv Grčke, ${ }^{54}$ Albert i Le Compte protiv Belgije, ${ }^{55}$ Campbell i Fell protiv Velike Britanije, ${ }^{56}$ Hadjianastassiou protiv Grčke, ${ }^{57}$ Kremzow protiv Austrije, ${ }^{58}$ Connolly protiv Velike Britanije $^{59}$ te Mayzit protiv Rusije, ${ }^{60}$ Dolenec protiv Hrvatske, ${ }^{61}$ Gregačević protiv Hrvatske, Mattoccia protiv Italije. ${ }^{62} \mathrm{U}$ praksi Ustavnog suda $\mathrm{BiH}$ o ovom pravu se raspravljalo u predmetu u kojem je potvrđeno stajalište ESLJP-a da se ovo pravo ne odnosi samo na osumnjičenika, nego i na branitelja, tako da se pri ocjeni je li došlo do povrede ovog prava ocjenjuje položaj obojice te da obrana na raspolaganju mora imati dovoljno vremena pripreme za obranu i odgovore te mogućnost djelotvorno izložiti sudu sve relevantne argumente i time utjecati na ishod postupka. ${ }^{63}$ Također, u predmetu Dolenec protiv Hrvatske ESLJP navodi da to što čl. 6. st. 3. t. b) EKLJP-a jamči osumnjičeniku pravo na odgovarajuće vrijeme i mogućnost za pripremu obrane podrazumijeva “(...) aktivnosti obrane koje se poduzimaju u ime optuženika mogu obuhvaćati sve ono što je 'potrebno' za pripremu glavne rasprave. Optuženiku se mora omogućiti da svoju obranu organizira na odgovarajući način i bez ikakvih ograničenja glede mogućnosti podnošenja svih relevantnih argumenata obrane..." S druge strane, kad je riječ o mogućnostima koje osumnjičenik ima za pripremu obrane, to znači da mu se treba omogućiti da se upravo u tu svrhu upozna s rezultatima istraga koje su se vodile tijekom cijeloga postupka. ${ }^{64}$

\subsection{PRAVO NA RAZMATRANJE SPISA I DOKUMENTACIJE}

Pravo razmatranja spisa predmeta također je odraz pravičnog postupka u stadiju istrage. ${ }^{65}$ U stvari, pravo razmatranja spisa je odraz načela jednakosti oružja stranaka u postupku. Pre-

(2016) Pravosudna akademija, 51, <http://pak.hr/cke/obrazovni\%20materijali/odabrana\%20 poglavlja\%20EKLJP\%20-\%20 kaznenopravni\%20aspekt.pdf> pristupljeno 16. srpnja 2021.

Twalib v Greece App no 42/1997/826/1032 (ECtHR, 9 June 1998).

Albert and Le Compte v Belgium App no 7299/75, 7496/76 (ECtHR, 10 February 1983).

Campbell and Fell $v$ The United Kingdom App no 7819/77, 7878/77 (ECtHR, 28 June 1984).

Hadjianastassiou v Greece App no 12945/87 (ECtHR, 16 December 1992).

Kremzow v Austria App no 12350/86 (EctHR 21 September 1993).

Bernard Connolly v Commission of the European Communities T-34/96 and T-163/96 (ECJ 6 March 2001).

Mayzit v Russia App no 63378/00 (ECtHR, 20 January 2005).

Dolenec protiv Hrvatske od 26. studenog 2009.; Gregačević protiv Hrvatske od 10. srpnja 2012., prema: Matko Pajčić i Laura Valković, 'Presude Europskog suda za ljudska prava protiv Republike Hrvatske zbog povrede prava na pravično suđenje' (2012) 19(2) Hrvatski ljetopis za kazneno pravo i praksu, 784-791; Ćamil Salahović i Davor Bubalo (n 48) 246-247.

Mattoccia v Italy App no 23969/94) (ECtHR, 25 July 2000); Ibid 231.

Odluka Ustavnog suda BiH AP-2613/11 USBiH (9. srpnja 2015.).

O tome i Galstyan v Armenia App no 26986/03 (ECtHR, 15 November 2007).

Vidjeti: Matko Pajčić, 'Pravo okrivljenika na uvid u spis predmeta tijekom prethodnog kaznenog postupka u pravnim sustavima nekih europskih država i praksi Europskog suda za ljudska prava' (2010) 17(2) Hrvatski ljetopis za kazneno pravo i praksu, 25-52. 
ma ZKP-u BiH pravo osumnjičenika na razmatranje spisa i razgledanje predmeta pribavljenih tijekom istrage ograničeno je jer je zakonodavac suzio vrstu dokaznog materijala u koju osumnjičenik, odnosno njegov branitelj imaju pravo uvida u istrazi. Tako je pristup spisu predmeta, odnosno pribavljenim dokazima, dopušten ako su u korist osumnjičenika (pod uvjetom da to ne dovodi u opasnost cilj istrage), a onemogućen ako su na štetu osumnjičenog. ${ }^{66}$ Jedina iznimka koju ZKP BiH predviđa jest da tužitelj istodobno s prijedlogom za određivanje pritvora sucu za prethodni postupak, odnosno sucu za prethodno saslušanje dostavlja i dokaze bitne za procjenu zakonitosti pritvora i radi izvješćivanja branitelja. ${ }^{67}$ Dakle, da bi ostvarilo pravo na obranu, osumnjičeniku i njegovu branitelju mora se omogućiti pristup spisu predmeta. Međutim, time što je zakonodavac ograničio ovo pravo pristupom samo onom dokaznom materijalu koji ide u korist osumnjičeniku, onemogućio je jednakost oružja u prethodnom postupku s obzirom na to da u ovom stadiju postupka osumnjičenik nema potpuno saznanje o onome što mu se stavlja na teret. Osim toga, postavlja se pitanje tko je nadležan utvrditi koji je dio spisa u korist, a koji na štetu osumnjičenog, odnosno na koji način će osumnjičenik i njegov branitelj ostvariti ovo pravo. U većini slučajeva tu procjenu vrši tužitelj, osobito u slučajevima kad prema osumnjičeniku nije poduzeta ni jedna radnja i mjera koja zahtijeva sudsko odobrenje. Dakle, osumnjičenik u istrazi nema instrument kojim bi se učinkovito zaštitio od slobodne procjene tužitelja te kojim bi ostvario ovo svoje pravo.

Valja imati u vidu da pravo razgledavanja spisa predmeta nastupa nakon prve radnje koju je poduzeo tužitelj i to nakon donošenja naredbe o provođenju istrage. Umjesto ranije formulacije prema kojoj je razmatranje i razgledavanje bilo moguće u tijeku cijelog postupka, čime se otvaralo pitanje kad postupak počinje, u sadašnjem tekstu čl. 47. st. 1. ZKP-a BiH točno je označeno od kojeg trenutka u postupku je (u tijeku istrage) razmatranje i razgledavanje moguće. Razlozi zbog kojih se privremeno može uskratiti pravo osumnjičenika, odnosno njegova branitelja na razmatranje spisa kada to zahtijevaju interesi istrage jesu težina kaznenog djela, broj osumnjičenih, otkrivanje dokaza za koje postoji opasnost od odlaganja, interesi čuvanja tajne, interesi javnog reda ili razlozi morala i sl. O uskraćivanju razmatranja spisa i razgledavanja predmeta tužitelj ne donosi nikakvu odluku pa je samim time isključena mogućnost žalbe na takav postupak tužitelja. ${ }^{68}$

S druge strane, prema čl. 184. ZKP-a RH ne pravi se razlika u vrsti spisa na koje osumnjičenik i njegov branitelj imaju pravo uvida. Štoviše, i u slučaju opasnosti da će se uvidom u dio ili cijeli spis ugroziti svrha istrage ZKP RH propisuje privremenu uskratu prava na uvid u spis najdulje trideset dana od dana dostave rješenja o provođenju istrage na koje osumnjičenik ima pravo žalbe u roku od tri dana. ${ }^{69}$ I sam ESLJP dao je neke upute u vezi s materijalima kojima osumnjičenik ili okrivljenik mora imati pristup, u vezi sa stadijem postupka u kojem mu takav pristup mora biti omogućen. Tako je primjerice, u odnosu na preispitivanje zakonitosti pritvora ESLJP našao da osumnjičenik mora imati pravo pristupa svim dokumentima u istražnom

66 Članak 47. ZKP-a BIH: "U tijeku istrage branitelj ima pravo da razmatra spise i razgleda pribavljene predmete koji su u korist osumnjičenog. Ovo pravo se branitelju može uskratiti ako je riječ o spisima i predmetima čije bi otkrivanje moglo dovesti u pitanje cilj istrage."

67 Članak 131. ZKP-a BiH; O povredi ovog prava vidjeti Rješenje Vrhovnog suda Federacije Bosne i Hercegovine broj: 070-0-Kž-09000449 od 6. listopada 2009.

68 Hajrija Sijerčić Čolić i drugi, (n 4) 167.

69 Članak 184.a ZKP-a RH. 
spisu koji su nužni kako bi se učinkovito preispitala zakonitost odluke o oduzimanju slobode. ESLJP dopušta da pristup određenim materijalima, kada postoji opasnost da bi osumnjičenikov ili okrivljenikov pristup tim materijalima mogao ugroziti interese istrage, može ostvariti samo branitelj okrivljenika. ${ }^{70}$

\section{INSTRUMENTI ZAŠTITE POSTUPOVNIH PRAVA OBRANE U ISTRAZI}

\subsection{POREDBENI PRIKAZ INSTRUMENATA ZAŠTITE POSTUPOVNIH PRAVA OBRANE U ISTRAZI}

O djelotvornom pravnom lijeku i sudskoj zaštiti prava obrane u istrazi pisali su određeni teoretičari i praktičari navodeći da je to pravo u središtu ideje o zaštiti ljudskih prava i sloboda. ${ }^{71}$ Pravo na djelotvoran pravni lijek u istrazi omogućava provođenje učinkovite obrane uz poštovanje načela presumpcije nevinosti. U ovom dijelu rada, autori iznose poredbenopravni prikaz nekih poredbenih rješenja radi usporedbe s de lege lata odredbama ZKP-a BiH. Tako, za razliku od ZKP-a BiH, u ZKP-u RH je osigurana zaštita postupovnih prava obrane $\mathrm{u}$ istrazi primarno žalbom na rješenje o provođenju istrage. Dakle, ponajprije propisana je obveza dostavljanja rješenja o provođenju istrage osumnjičeniku i to najkasnije u roku od osam dana od dana donošenja rješenja, zajedno s poukom o pravima. ${ }^{72}$ Protiv rješenja o provođenju istrage okrivljenik ima pravo žalbe sucu istrage $u$ roku od osam dana od dana primitka rješenja. ${ }^{73} \mathrm{Na}$ taj način osiguran je prvi korak u zaštiti prava okrivljenika $u$ istrazi kroz sudsku kontrolu rješenja o provođenju istrage. Međutim, teoretičari i praktičari u Republici Hrvatskoj ukazuju na neka sporna pitanja glede ovog prava. Tako se kao sporno, postavljalo pitanje je li rok u kojem sudac istrage donosi odluku o žalbi okrivljenika na rješenje o provođenju istrage predugačak, a koje se postavljalo zato što prema odredbi čl. 218. st. 4. ZKP-a RH državni odvjetnik nije ovlašten provoditi istragu, nego tek ako sudac istrage ne odluči u tom roku, državni odvjetnik može nastaviti s provođenjem istrage. Neki autori ističu da taj rok nije predug ako se uzme u obzir da se sudac istrage tek tada prvi put susreće sa spisom, a osobito ako je riječ o složenim predmetima s više okrivljenika i većim brojem kaznenih djela, nije realno očekivati da taj rok bude kraći. ${ }^{74}$ Drugo je pitanje treba li žalba okrivljenika protiv rješenja o provođenju istrage imati takav suspenzivni karakter u odnosu na pravo državnog odvjetnika da provodi istragu, odnosno prikuplja dokaze. Neki smatraju da je besmisleno prekidati istragu zbog odlučivanja o žalbi te da bi odredbu čl. 218. st. 4. ZKP-a RH trebalo revidirati na način da podnesena žalba

70 Marin Mrčela, Dražen Tripalo i Laura Valković (n 53)54.

71 Tako: Ksenija Vržina, 'Zaštita postupovnih prava obrane' (2015) 22(1) Hrvatski ljetopis za kazneno pravo i praksu, 217-242; Matko Pajčić, 'Istraga prema Noveli Zakona o kaznenom postupku' (2013) 20(2) Hrvatski ljetopis za kazneno pravo i praksu 631-661.

72 Članak 218. st. 1. ZKP-a RH.

73 Članak 218. st. 2. ZKP-a RH.

74 Tako: Ante Novokmet i Miroslav Jukić, 'Sudska kontrola prethodnog postupka - Istraživanje prakse županijskih sudova u Osijeku, Splitu, Rijeci, Varaždinu i Zagrebu’ (2015) 2(2) Hrvatski ljetopis za kazneno pravo i praksu (Zagreb) 468. 
ne zadržava izvršenje rješenja o provođenju istrage. ${ }^{75}$ Međutim, u ideji zaštite prava obrane u istrazi jest da se protiv nedužnih građana istrage ne provode arbitrarno te se žalbom omogućava preispitati postojanje zakonskih uvjeta za provođenje istrage, pozitivnih (postojanje osnovane sumnje) i negativnih (nepostojanje zakonskih smetnji kaznenom progonu), smatramo da takav pravni lijek treba imati suspenzivni karakter.

Unatoč određenim kritikama de lege lata rješenjima kaznenog procesnog zakonodavstva, hrvatski zakonodavac otišao je i korak dalje pa je u strukturu prethodnom postupka ugradio i prigovor zbog povrede postupovnih prava obrane u prethodnom postupku. ${ }^{76}$ Ovo pravno sredstvo nastalo je kao rezultat odluke Ustavnog suda RH broj U-I-448/2009 od 19. srpnja 2012. godine kojom je, među ostalim, propisana pozitivna obveza zakonodavcu da „u strukturu prethodnog postupka ugradi mehanizam djelotvorne sudske zaštite protiv nezakonitog (arbitrarnog) kaznenog progona i istrage" ${ }^{77}$ Osim toga, propisano je da se prigovor ne može podnijeti iz razloga zbog kojih se može podnijeti žalba protiv rješenja državnog odvjetnika o provođenju istrage. To znači da će se u stadiju istrage ovo pravno sredstvo koristiti samo za sudsku kontrolu uskrate ili povrede postupovnih prava obrane. ${ }^{78}$ Trenutak stjecanja prava na uporabu ovog pravnog sredstva u slučajevima vođenja istrage jest dostava rješenja o provođenju istrage. ${ }^{79}$ Nakon dostave rješenja o provođenju istrage okrivljenik koji smatra da mu je protivno zakonu uskraćeno ili povrijeđeno određeno pravo, može podnijeti državnom odvjetniku pisani prigovor koji sadržava oznaku predmeta, odluke ili radnje na koju se odnosi, razloge prigovora i prijedlog načina ostvarivanja uskraćenog prava. Državni odvjetnik će odmah, a najkasnije u roku od osam dana od dana primitka prigovora, donijeti odluku. Ako državni odvjetnik ne prihvati prigovor u tom roku, dostavit će ga sucu istrage koji će odmah, a najkasnije u roku od osam dana od primitka, odlučiti o prigovoru. Ako sudac istrage prihvati taj prigovor, a moguće je ostvarenje određenog prava ili provođenje odnosno ponavljanje radnje, naložit će državnom odvjetniku ostvarenje tog prava ili provođenje odnosno ponavljanje radnje u određenom roku. ${ }^{80}$

Osim prigovora zbog povrede postupovnih prava obrane te žalbe protiv rješenja o provođenju istrage, hrvatski zakonodavac predviđa i druga pravna sredstva u cilju podizanja pravne zaštite postupovnih prava obrane $u$ istrazi. Ta su pravna sredstva pritužba višem državnom odvjetniku zbog odugovlačenja postupka i drugih nepravilnosti tijekom istrage, prigovor sucu

75 Ibid 469.

76 Članak 239.a ZKP-a RH.

77 Točka 39.8, 246., Odluke Ustavnog suda RH. U obrazloženju se navodi (str. 137.): „Valja napomenuti da se Ustavni sud Republike Hrvatske u svojoj odluci referirao na obavijest o statusu osumnjičenika, budući da je prema dosadašnjem konceptu za provođenje istrage i dokaznih radnji bila dostatna osnova sumnje o učinu kaznenog djela, što je sada izmijenjeno na stupanj osnovane sumnje, zbog čega se to pravno sredstvo veže za rješenje o provođenju istrage i obavijest o provedenoj prvoj dokaznoj radnji, kao trenucima u kojima osoba, po novom konceptu, stječe svojstvo okrivljenika.“

Matko Pajčić, Istraga prema Noveli Zakona o kaznenom postupku, (n 71) 653-654.

79 U obrazloženju (str. 138.-139.): „Izvršavajući odluku Ustavnog suda Republike Hrvatske, zakonopisac je ovo pravno sredstvo zaštite protiv nezakonitog (arbitrarnog) kaznenog progona vezao uz trenutak u kojem se osoba formalno obavještava da je u statusu okrivljenika, što znači u stadiju istrage dostavom rješenja o provođenju istrage (uz koji trenutak je vezana I žalba protiv tog rješenja, kao vid izvršavanja ustavne obveze propisivanja djelotvorne sudske zaštite u prethodnom postupku od nezakonitog kaznenog progona), a u stadiju istraživanja uz trenutak dostave obavijesti iz članka 213. stavka 2., budući da se time formalno obavještava okrivljenik da je državni odvjetnik utvrdio postojanje zakonom propisanog stupnja sumnje, osnovane sumnje, da je počinio kazneno djelo za koje se ne provodi istraga“, Loc. cit. 
istrage zbog odugovlačenja postupka i pritužba zbog nepostupanja suda u zakonskim rokovima u prethodnom postupku. Karakteristična za stadij istrage pritužba je zbog nepostupanja suda u zakonskim rokovima u prethodnom postupku. ${ }^{81}$ Kako navodi Pajčić, pritužba se može podnijeti ne samo zbog nepostupanja suda u zakonskim rokovima (kao što bi to proizlazilo iz naziva), već i zbog nepoduzimanja radnji suca istrage koje dovodi do odugovlačenja postupka, čak i kada nisu propisani rokovi za poduzimanje tih radnji. ${ }^{82}$

U Republici Austriji u Zakonu o kaznenom postupku ${ }^{83}$ postoje dva prigovora koja stoje na raspolaganju osumnjičeniku u istrazi: prigovor zbog povrede prava ( $\$ 106$. StPO Einspruch wegen Rechtsverletzung) i zahtjev za obustavu kaznenog postupka ( $§ 108$. StPO Antrag auf Einstellung). Svaka osoba koja tvrdi da joj je tijekom istražnog postupka od strane kriminalističke policije ili državnog odvjetništva povrijeđeno neko subjektivno pravo ima pravo na prigovor sudu jer joj je korištenje nekog prava sukladno StPO-u uskraćeno ili je povredom odredaba StPO-a naložena ili provedena istražna ili prisilna mjera (§ 106. st. 1. StPO-a). S druge strane, zahtjev za obustavu pravno je sredstvo u povodu kojega sud preispituje zakonitost i osnovanost pokretanja i vođenja istražnog postupka. Riječ je o pravu okrivljenika da podnese zahtjev sudu za obustavu istražnog postupka ako smatra da djelo nije kazneno djelo, nema pretpostavki ili postoje zapreke za kazneni progon ili je trajanje postupka nerazmjerno. ${ }^{84}$

Država istog pravnog kruga, Savezna Republika Njemačka, slično kao i BiH nije konstituirala obvezu niti upoznavanja osmnjičenika s provođenjem istrage, niti je u njemačkom Zakonu o kaznenom postupku ${ }^{85}$ predviđeno pravno sredstvo zaštite postupovnih prava obrane $u$ istrazi. Općenito, njemački ZKP bio je kamen-temeljac donošenju sadašnjeg ZKP-a BiH, pa ne čudi činjenica da oba zakona imaju slične odredbe glede ovog pitanja. To uočavamo i u tumačenjima Ustavnog suda BiH kroz zahtjev za ocjenu ustavnosti u kojem je Ustavni sud BiH zauzeo stajalište slično onomu koje prevladava u Njemačkoj da „istražni postupak predstavlja samo skup 'nesamostalnih pojedinačnih mjera' koje još ne utječu na pravne odnose okrivljenika. Načelno, mjere u istražnom postupku nemaju odlučujući, već isključivo pripremni karakter jer pripremaju konačnu odluku o podizanju optužnice ili obustavi postupka. Stoga, smatra se da prava okrivljenika nisu povrijeđena pokretanjem istražnog postupka, posljedicama istražne djelatnosti kao ni neobustavom istražnog postupka“. ${ }^{86}$ Zaštita pojedinih prava moguća je samo ako istražne radnje predstavljaju prisilne mjere koje zadiru u temeljna prava uređena Temeljnim zakonom. ${ }^{87}$

81 Članak 347. ZKP-a RH.

82 Matko Pajčić, Istraga prema Noveli Zakona o kaznenom postupku(n 71) 657.

83 Strafprozeßordnung 1975 <www.jusline.at/gesetz/stpo> pristupljeno 16. srpnja 2021. (dalje u tekstu: StPO)

84 KsenijaVržina (n 71) 220-221.

85 Strafprozeßordnung in der Fassung der Bekanntmachung vom 7. April 1987 (BGBl. I S. 1074, 1319), die zuletzt durch Artikel 15 des Gesetzes vom 7. Juli 2021 (BGBl. I S. 2363) geändert worden ist <www.gesetze-im-internet.de/stpo/BJNR006290950. html> pristupljeno 16. srpnja 2021.(dalje u tekstu: njemački ZKP).

86 Zlata Đurđević, 'Sudska kontrola državnoodvjetničkog kaznenog progona i istrage: poredbenopravni i ustavni aspekt' (2010) 17(1) Hrvatski ljetopis za kazneno pravo i praksu 11.

87 Članak 19. st. 4. Temeljnog zakona Grundgesetz für die Bundesrepublik Deutschland in der im Bundesgesetzblatt Teil III, Gliederungsnummer 100-1, veröffentlichten bereinigten Fassung, das zuletzt durch Artikel 1 u. 2 Satz 2 des Gesetzes vom 29. September 2020 (BGBl. I S. 2048) geändert worden ist <www.gesetze-im-internet.de/gg/BJNR000010949.html> pristupljeno 16. srpnja 2021. 
U Nizozemskoj je ne tako davno tek uveden model tužiteljskog kaznenog progona i istrage, a sudski model je napušten 1. siječnja 2013. godine. Kao u već navedenim državama, sudska uloga u istrazi u Nizozemskoj kontrola je nad čitavom istragom, osobito legitimnim korištenjem istražnih ovlasti, praćenja napretka istrage i sl. Upravo je radi procjene napretka istrage nizozemski zakonodavac predvidio pravno sredstvo osumnjičenika u vidu prigovora zbog odugovlačenja postupka sucu istrage. ${ }^{88}$ Međutim, jednako kao BiH i Njemačka, Nizozemska ne predviđa instrumente koji bi poslužili obrani u istrazi da osporava navode rješenja o provođenju istrage kakvi postoje u Hrvatskoj i Austriji.

\subsection{BOSNA I HERCEGOVINA}

Donošenjem ZKP-a BiH 2003. godine u bosanskohercegovački kaznenoprocesni sustav uveden je akuzatorski koncept istrage prema kojem istragu vodi i nadzire tužitelj. Premda akuzatorski koncept istrage izvorno pripada anglosaksonskom pravnom sustavu, u bosanskohercegovačkom kaznenom procesnom pravu on se miješa s kontinentalnim pravom pri čemu dobivamo mješoviti model u kojem i sudska uloga ima značajno mjesto. U stadiju istrage važnu ulogu igra sudac za prethodni postupak, osobito u ocjeni zaštite zakonitosti pojedinih procesnih radnji. Sud kao neovisno i nepristrano tijelo kaznenog postupka u duhu vladavine prava osigurava načelo jednakosti oružja stranaka u postupku. Međutim, prema važećem ZKP-u BiH tužitelj samostalno odlučuje o provođenju istrage $\mathrm{u}$ formi naredbe o provođenju istrage, za razliku od dosad prisutnog rješenja o provođenju istrage koje je donosio istražni sudac na prijedlog tužitelja. Dakle, tužitelj naređuje provođenje istrage ako postoje osnove sumnje da je počinjeno kazneno djelo. Na ovaj niži stupanj vjerojatnosti o počinjenju kaznenog djela već je ranije bilo riječi. ${ }^{89}$ Kontradiktornost de lege lata odredaba ZKP-a BiH nalazi se u tumačenju da o donošenju naredbe o provođenju istrage tužitelj ne obavještava osumnjičenika, dok u slučaju obustave istrage tužitelj obavještava osumnjičenika i to samo ako je ispitan. Samim time što osumnjičenik nije obaviješten o provođenju istrage protiv njega, nema ni mogućnost ulaganja pravnog lijeka na naredbu o provođenju istrage. Dakle, prema postojećem $\mathrm{ZKP}-\mathrm{u} \mathrm{BiH}$ ne postoji instrument koji bi poslužio obrani u istrazi da utječe na određene nepravilnosti ili nepravičnost u vođenju istrage u odnosu na samog osumnjičenika. Vratimo li se u ZKP SFRJ vidljivo je kako je zakonodavac propisao da osumnjičenik ima pravo žalbe na rješenje o provođenju istrage te ako je rješenje priopćeno usmeno, osumnjičenik ima pravo izjaviti žalbu na zapisnik. ${ }^{90}$ Pored žalbe na rješenje o provođenju istrage, ZKP SFRJ predviđao je i isticanje pritužbe predsjedniku suda zbog odugovlačenja postupka i drugih nepravilnosti u tijeku istrage. ${ }^{91}$ U tom slučaju predsjednik suda ispituje navode iz pritužbe, a ako je podnositelj zahtjeva to tražio, sud će ga obavijestiti o tome što je poduzeo. ${ }^{92}$ Slična odredba, iako modificirana, vraćena je u ZKP BiH, pa je zakonodavac regulirao da osumnjičenik ima pravo na pritužbu glavnom

88 Ante Novokmet, 'Sudska kontrola kaznenog progona prema Noveli Zakona o kaznenom postupku' (2013) 20(2) Hrvatski ljetopis za kazneno pravo i praksu 570, 573.

89 Vidjeti supra, 2-3.

90 Članak 150. st. 5. ZKP-a SFRJ.

91 Članak 172. st. 1. ZKP-a SFRJ.

92 Članak 172. st. 2. ZKP-a SFRJ. 
tužitelju zbog trajanja postupka. ${ }^{93}$ Međutim, prema ZKP-u RH osumnjičenik u prethodnom postupku ima pravo pritužbe i sucu istrage kao neovisnom i nepristranom tijelu, pored tužitelja. ${ }^{94}$ Osim toga, treba podsjetiti kako je jedna od temeljnih obveza suda paziti na svoju nadležnost tijekom cijelog postupka. Međutim, ta obveza je u istražnom postupku ograničena jer ne postoji ograničenje tužiteljstva da se proglasi nenadležnim u istrazi i ustupi predmet drugom entitetskom tužiteljstvu. Tako je u jednom predmetu Sud BiH dao tumačenje da bi u suprotnom slučaju, dakle kada bi odluku o nenadležnosti u istrazi donosio sud, isti bi imao obvezu takvo rješenje dostaviti osumnjičeniku, čime bi se prema stajalištu Suda $\mathrm{BiH}$ „(...) ugrozili ciljevi istrage i uspješno okončanje iste (...) tek u slučaju podizanja optužnice, stranke u postupku će u punoj mjeri ravnopravno imati mogućnost sudjelovati u postupku u kojem bi se eventualno odlučivalo o nadležnosti suda. U suprotnom samo postupajući tužitelj bi imao to pravo". ${ }^{95}$

Ovako koncipiran istražni postupak proizveo je dvostruku, ali i kontradiktornu ulogu osumnjičenika. S obzirom na slovo zakona, osumnjičenik u istrazi pravno uživa sva procesna prava od prvog pojavljivanja pred istražnim tijelima, ali s druge strane njegov je položaj nejednak u odnosu na drugu stranku postupka. U sadašnjem istražnom postupku osumnjičenik nema instrument kojim bi mogao osporiti temelj vođenja kaznene istrage protiv njega. I ne samo to. Prema sadašnjim normativnim rješenjima, osumnjičenik ne mora ni znati da se protiv njega vodi istraga ${ }^{96}$ jer u ZKP-u BiH nije konstituirana obveza tužitelja da ga o tome obavijesti, odnosno da mu dostavi naredbu o provođenju istrage. Tek ako tužitelj odluči već na samom početku istrage ispitati osumnjičenika, u obvezi je tijekom prvog ispitivanja priopćiti mu osnove sumnje koje stoje protiv njega. Međutim, u slučaju da do toga ne dođe, osumnjičenik sve do kraja istrage ne mora ni znati da se protiv njega priprema podizanje optužnice, čime mu se onemogućava korištenje prava na obranu u istrazi. Treba naglasiti da kada je u pitanju provođenje istražnih mjera i radnji, osumnjičenik odnosno njegov branitelj u njima ne sudjeluju aktivno, što potvrđuje i činjenica da u istrazi nije predviđena nazočnost osumnjičenika, odnosno branitelja pri provođenju pojedinih istražnih radnji, kao i činjenica da obrana nema pravo ispitivati svjedoke i sl. Nazočnost osumnjičenog, odnosno njegova branitelja u istražnom postupku pri provođenju određenih istražnih radnji predviđena samo kod onih radnji kojima se ograničavaju pojedina prava ili slobode građana (npr. pretraga), premda ni tada nije riječ o aktivnoj ulozi osumnjičenog, odnosno njegova branitelja nego o svojevrsnoj kontroli zakonitosti izvođenja određene istražne radnje, odnosno postojanju mogućnosti za stavljanje određenih prijedloga za osiguranje dokaza. Osim toga, uloga suda u istrazi dosta je ograničena. Tako se njegova temeljna uloga ogleda u izdavanju naredbe za provođenje određenih istražnih radnji, izricanju mjera zabrane, donošenju rješenja o jamstvu, određivanju pritvora i sl. S druge strane, osiguranje zaštite prava obrane u istrazi neodvojivo je od sudske kontrole prethodnog stadija kaznenog postupka.

93 Članak 225. st. 4. ZKP-a BiH. Ova odredba nastala je kao rezultat Odluke Ustavnog suda BiH br. U-5716 od 1. lipnja 2017. godine. Primjer sudske prakse: Odluka Ustavnog suda br. AP 3914/13 od 17. ožujka 2015. godine

94

Članak 229. st. 5. ZKP-a RH.

Rješenje Izvanraspravnog vijeća Suda BiH br. S1 2 K 01920016 Kv (12. listopada 2016.) u Bilten sudske prakse7/2017, str. 64-65.

Isto tako: Miodrag N Simović, Vladimir M Simović, Marina M Simović, 'Obilježja istrage u Zakonu o krivičnom postupku Bosne i Hercegovine: aktuelna pitanja i prioriteti de lege ferenda’ u Ivanović A (ed), Razmjena teorijskih znanja i praktičnih iskustava vezanih za rad po modelu tužilačke istrage i konceptu adverzalnog krivičnog postupka (Deartman za pravne nauke Internacionalnog univerziteta u Novom Pazaru 2014). 
Na problem nepostojanja djelotvorne sudske zaštite osumnjičenika u istrazi ukazuje i zahtjev $^{97}$ za ocjenu ustavnosti čl. 216. st. 2. ZKP-a BiH kojim se ističe da navedena odredba nije u skladu s čl. II/3 e) Ustava BiH te čl. 56. u vezi s čl. 13. EKLJP-a. U zahtjevu se ističe da način pokretanja istrage ne osigurava građanima djelotvoran pravni lijek protiv naredbe o provođenju istrage što predstavlja nedostatak sudske zaštite protiv nezakonitog kaznenog progona i istrage. Ustavni sud $\mathrm{BiH}$ nije usvojio zahtjev s obrazloženjem da “(...) je naredba o provođenju istrage interni i pripremni akt tužitelja (...) da samo donošenje naredbe o provođenju istrage ne proizvodi nikakve posljedice za osumnjičenog u smislu ograničenja njegovih prava. Ustavni sud podsjeća da tijekom istrage može doći do ograničenja određenih prava osumnjičenog (mjere za osiguranje nazočnosti, posebne istražne radnje), međutim tada osnova za ograničenje prava nije naredba za provođenje istrage kao interni i pripremni akt, nego odluka suda." ${ }^{8}$

Načelo vladavine prava podrazumijeva da zadiranje u prava pojedinca mora biti podložno učinkovitoj kontroli koju u pravilu treba vršiti sudstvo, bar u krajnjoj instanciji, zbog toga što sudska kontrola pruža najbolja jamstva neovisnosti, nepristranosti i pravilnog postupka. ${ }^{99} \mathrm{U}$ tom smjeru, naredba o provođenju istrage protiv određene osobe kao pravno sredstvo tužitelja direktno se manifestira na prava i slobode osumnjičenika te je potrebno osigurati jednakost oružja stranaka u prethodnom postupku. Osim toga, osumnjičenikovo je temeljno pravo znati da se protiv njega pokreće istraga kako bi se osigurala minimalna prava obrane u istrazi. Pokretanje istrage protiv određene osobe ne znači samo provođenje određenih dokaznih mjera, nego je potrebno osigurati da sve strane u prethodnom postupku imaju mogućnost iznošenja dokaza i činjenica koje im idu u korist. Tako se osigurava provođenje načela pravičnog postupka. Osim toga, kako i sam Ustavni sud BiH navodi u obrazloženju odluke, da bi došlo do ograničenja pojedinih prava osumnjičenika potrebno je da sud slobodno i nepristrano odluči o provođenju pojedinih dokaznih radnji. Na jednak način potrebno je osigurati da obrana ima mogućnost djelotvorne sudske zaštite u prethodnom postupku kroz instrumente kakvi postoje u poredbenim sustavima. De lege ferenda prijedlozi u odnosu na ZKP BiH jesu ponajprije obveza tužitelja da obavijesti osumnjičenika o donošenju naredbe za provođenje istrage jer se na taj način ostvaruje pravo na obranu. Nadalje, nakon dostavljanja naredbe o provođenju istrage, osumnjičeniku, odnosno njegovu branitelju, treba se omogućiti ulaganje pravnog sredstva na naredbu, u prvom redu žalbe na naredbu.

\section{ZAKLJUČAK}

Istražni postupci od iznimne su važnosti za pripremu suđenja. O zakonitoj i pravilnoj istrazi ovisi daljnji tijek suđenja, stoga je nužno osigurati pravično provođenje istrage. Ideja zaštite procesnih prava obrane i u judikaturi ESLJP pomjerena je na istražne postupke. U tom smislu, oslanjajući se na načelo pravičnog suđenja te načelo jednakosti oružja, uočeno je da prava obrane u istrazi prema bosanskohercegovačkom kaznenoprocesnom zakonodavstvu ne uživaju djelotvornu sudsku zaštitu na što ukazuju de lege lata odredbe ZKP-a BiH. Analizom kazne-

Zahtjev za ocjenu ustavnosti br. U-5/16 od 1. srpnja 2016.

98 Točka VI.5. Odluke Ustavnog suda BiH br. U-5/16 od 29. lipnja 2017. 
noprocesnog zakonodavstva $\mathrm{BiH}$ utvrđeno je da osumnjičenik u istrazi nema instrument kojim bi učinkovito osporavao navode buduće optužnice, a što proizlazi iz mogućnosti arbitrarnog postupanja tužitelja koji vodi istragu. Da bi se osigurala djelotvorna sudska zaštita osumnjičenika u obrani primarno je potrebno osigurati da osumnjičenik bude obaviješten o donošenju naredbe o provođenju istrage kako bi mogao pravovremeno pripremati svoju obranu te kako bi mu se osigurao djelotvoran pravni lijek protiv naredbe o provođenju istrage kakav egzistira u hrvatskom kaznenoprocesnom zakonodavstvu. Osim toga, u Hrvatskoj je uveden i novi institut zaštite postupovnih prava u obrani, a to je prigovor zbog povrede postupovnih prava obrane u prethodnom postupku koji osigurava mogućnost zahtijevati preispitivanje zakonske osnovanosti progona ako su, primjerice, osnove sumnje utvrđene arbitrarno. Jedini instrument koji bosanskohercegovački zakonodavac predviđa u svrhu provođenja zakonite istrage je pritužba tužitelju zbog trajanja postupka koja je nastala kao rezultat Odluke Ustavnog suda BiH od 1. lipnja 2017. godine. Međutim, i ovdje uočavamo nedostatak sudske kontrole u odlučivanju o pritužbama zbog odugovlačenja postupka i drugih nepravilnosti tijekom istrage jer o istima odlučuje tužitelj, a ne sud kao neovisno tijelo. Stoga, imajući u vidu da je cilj istrage potpuno i točno utvrđivanje svih relevantnih činjenica i okolnosti vezanih za kazneno djelo i počinitelja, kako u smislu rasvjetljavanja počinjenih kaznenih djela i počinitelja, tako i osiguranja načela da nitko nevin ne bude kazneno progonjen niti osuđen, potrebno je osigurati jednakost oružja svim sudionicima prethodnog postupka što je odraz poštivanja temeljnog načela kaznenog postupka - načela na pravično suđenje. U odnosu na $\mathrm{ZKP} \mathrm{BiH}$ to bi značilo temeljite izmjene u pogledu provođenja istrage s naglaskom na osiguranje zaštite prava obrane $\mathrm{u}$ istrazi kroz pravna sredstva kakva postoje u poredbenim sustavima te učinkovitiju ulogu suda u vidu sudske kontrole pravnih instrumenata tužitelja u prethodnom postupku. Kako je navedeno, to bi se odnosilo primarno na osiguranje prava na obavijest o donošenju naredbe o provođenju istrage u zakonom određenom roku, mogućnost ulaganja pravnog lijeka protiv naredbe, u prvom redu žalbe, te sudsko odlučivanje o žalbi kao i u krajnjem slučaju pritužbi zbog odugovlačenja postupka.

\section{BIBLIOGRAFIJA}

1. Đurđević $Z$, 'Sudska kontrola državnoodvjetničkog kaznenog progona i istrage: poredbenopravni i ustavni aspekt' (2010) 17(1) Hrvatski ljetopis za kazneno pravo i praksu 7

2. Ivičević Karas E, 'Pomicanje granica prava na branitelja pod utjecajem europskog kaznenog prava' (2015) 22(2) Hrvatski ljetopis za kazneno pravo i praksu 355

3. Karas Ž, 'Sudska praksa o policijskom postupanju: osnove sumnje i osnovana sumnja, zatvoreni krug indicija' (2011) 20(4) Policija i sigurnost 617

4. Mrčela M, Tripalo D i Valković L, 'Odabrana poglavlja Europske konvencije o ljudskim pravima i temeljnim slobodama: kaznenopravni aspekt' (Pravosudna akademija 2016) <http://pak.hr/cke/ obrazovni\%20materijali/Odabrana\%20poglavlja\%20EKLJP\%20-\%20kaznenopravni\%20aspekt. pdf> pristupljeno 16. srpnja 2021.

5. Novokmet A, 'Sudska kontrola kaznenog progona prema Noveli Zakona o kaznenom postupku' (2013) 20(2) Hrvatski ljetopis za kazneno pravo i praksu 555 
6. Novokmet A i Jukić M, 'Sudska kontrola prethodnog postupka: istraživanje prakse županijskih sudova u Osijeku, Splitu, Rijeci, Varaždinu i Zagrebu’ (2015) 22(2) Hrvatski ljetopis za kazneno pravo i praksu 453

7. Novokmet A i Sršen Z, 'Neučinkoviti kazneni postupak pred sudovima - implementacija presuda Europskog suda za ljudska prava' (2017) 24(2) Hrvatski ljetopis za kaznene znanosti i praksu 293

8. Pajčić M, 'Pravo okrivljenika na uvid u spis predmeta tijekom prethodnog kaznenog postupka u pravnim sustavima nekih europskih država i praksi Europskog suda za ljudska prava' (2010) 17(1) Hrvatski ljetopis za kazneno pravo i praksu 25

9. Pajčić M, 'Istraga prema Noveli Zakona o kaznenom postupku' (2013) 20(2) Hrvatski ljetopis za kazneno pravo i praksu 631

10. Pajčić M i Valković L, 'Presude Europskog suda za ljudska prava protiv Republike Hrvatske zbog povrede prava na pravično suđenje' (2012) 19(2) Hrvatski ljetopis za kazneno pravo i praksu 751

11. Salahović Ć i Bubalo D, 'Pravo na obranu prema Zakonu o kaznenom postupku Republike Hrvatske' (2016) 9(17) Anali Pravnog Fakulteta Univerziteta u Zenici 223

12. Sijerčić Čolić H i drugi, Komentari zakona o krivičnom/kaznenom postupku u Bosni i Hercegovini, (Zajednički projekat Vijeća Evrope i Evropske komisije 2005)

13. Sijerčić Čolić H, Krivično procesno pravo: Tok redovnog krivičnog postupka i posebni postupci, vol 2 (četvrto izdanje, Pravni fakultet Univerziteta u Sarajevu 2017)

14. Simović, M, Simović, V, Simović, M, 'Obilježja istrage u Zakonu o krivičnom postupku Bosne i Hercegovine: aktuelna pitanja i prioriteti de lege ferenda' u Ivanović A (ed) Razmjena teorijskih znanja i praktičnih iskustava vezanih za rad po modelu tužilačke istrage i konceptu adverzalnog krivičnog postupka (Deartman za ravne nauke Internacionalnog univerziteta u Novom Pazaru 2014)

15. Tegeltija M i drugi, Krivična oblast: istražni postupak, Modul 1 (Visoko sudsko i tužilačko vijeće Bosne i Hercegovine 2006) <www.pravosudje.ba/vstv/faces/docservlet?p_id_doc=346 $\geq$ pristupljeno 16. srpnja 2021.

16. Valković L, 'Procesna prava obrane prema V. Noveli Zakona o kaznenom postupku' (2013) 20(2) Hrvatski ljetopis za kazneno pravo i praksu 521

17. Valković L, 'Pravo na pristup branitelju u svjetlu presude Dvorski protiv Hrvatske' (2016) 23(2) Hrvatski ljetopis za kaznene znanosti i praksu 339

18. Valković L, 'Pravo na branitelja u praksi nacionalnih sudova i praksi Europskog suda za ljudska prava (pregled novijih odluka)' u Novine u kaznenom zakonodavstvu 2019: zbornik radova (Vrhovni sud Republike Hrvatske i Pravosudna akademija, Opatija 6-7 svibnja 2019) 97

19. Valković L i Burić $Z$, 'Primjena izabranih elemenata prava na formalnu obranu iz prakse Europskog suda za ljudska prava u hrvatskom kaznenom postupku' (2011) 18(2) Hrvatski ljetopis za kazneno pravo i praksu 521

20. Vržina K, 'Zaštita postupovnih prava obrane' (2015) 22(1) Hrvatski ljetopis za kazneno pravo i praksu 217

\section{PROPISI I DOKUMENTI}

1. Direktiva 2013/48/EU Europskog parlamenta i Vijeća od 22. listopada 2013. o pravu na pristup odvjetniku u kaznenom postupku i u postupku na temelju europskog uhidbenog naloga te o pravu na obavješćivanje treće strane u slučaju oduzimanja slobode i na komunikaciju s trećim osobama i konzularnim tijelima [2013] OJ 294/1 
2. Grundgesetz für die Bundesrepublik Deutschland in der im Bundesgesetzblatt Teil III, Gliederungsnummer 100-1, veröffentlichten bereinigten Fassung, das zuletzt durch Artikel 1 u. 2 Satz 2 des Gesetzes vom 29. September 2020 (BGBl. I S. 2048) geändert worden ist <www.gesetze-im-internet.de/gg/BJNR000010949.html> pristupljeno 16. srpnja 2021.

3. Strafprozeßordnung 1975 <www.jusline.at/gesetz/stpo> pristupljeno 16. srpnja 2021. (DE)

4. Strafprozeßordnung in der Fassung der Bekanntmachung vom 7. April 1987 (BGBl. I S. 1074, 1319), die zuletzt durch Artikel 15 des Gesetzes vom 7. Juli 2021 (BGBl. I S. 2363) geändert worden ist <www.gesetze-im-internet.de/stpo/BJNR006290950.html〉 pristupljeno 16. srpnja 2021. (DE)

5. Swiss Criminal Procedure Code: of 5 October 2007 (Status as of 1 July 2021) <www.admin.ch/opc/ en/classified-compilation/20052319/index.html> pristupljeno 16. srpnja 2021. (CH)

6. Zakon o kaznenom postupku (NN 152/2008, 76/2009, 80/2011, 121/2011, 91/2012, 143/2012, 56/2013, 145/2013, 152/2014, 70/2017, 126/2019, 126/2019) (HR)

7. Zakon o kaznenom postupku Bosne i Hercegovine (SG BiH 3/2003, 32/2003, 36/2003, 26/2004, 63/2004, 13/2005, 48/2005, 46/2006, 29/2007, 53/2007, 58/2008, 12/2009, 16/2009, 53/2009, 93/2009, 72/2013, 65/2018) (BA)

8. Zakon o krivičnom postupku (SL 4/1977, 36/1977, 14/1985, 26/1986, 74/1987, 57/1989, 3/1990) (YU)

9. Zakon o krivičnom postupku objašnjen sudskom praksom (deseto izdanje, Službeni list SFRJ 1983) (YU)

\section{PRESUDE I DRUGE ODLUKE}

1. Albert and Le Compte v Belgium App no 7299/75, 7496/76 (ECtHR, 10 February 1983)

2. Campbell and Fell $v$ The United Kingdom App no 7819/77, 7878/77 (ECtHR, 28 June 1984)

3. Bernard Connolly $v$ Commission of the European Communities T-34/96 and T-163/96 (ECJ 6 March 2001)

4. Dolenec v Croatia App no 25282/06 (ECtHR, 26 November 2009)

5. Gäfgen $v$ Germany App no 22978/05 (ECtHR, 1 June 2010)

6. Galstyan v Armenia App no 26986/03 (ECtHR, 15 November 2007)

7. Gregačević v Croatia App no 58331/09 (ECtHR, 10 July 2012)

8. Hadjianastassiou v Greece App no 12945/87 (ECtHR, 16 December 1992)

9. Heaney and Mcguinness v Ireland App no 34720/97 (ECtHR, 21 December 2000)

10. Ibrahim and others $v$ The United Kingdom App no 50541/08, 50571/08, 50573/08 and 40351/09 (ECtHR, 13 September 2016)

11. Kremzow v Austria App no 12350/86 (ECtHR 21 September 1993)

12. Mattoccia $v$ Italy App no 23969/94) (ECtHR, 25 July 2000)

13. Mayzit $v$ Russia App no 63378/00 (ECtHR, 20 January 2005)

14. Odluka AP-2238/05 USBiH (17. studenog 2006.)

15. Odluka AP-2613/11 USBiH (9. srpnja 2015.)

16. Odluka AP-3914/13 USBiH (17. ožujka 2015.)

17. Odluka AP-506/04 USBiH (23. rujna 2005.) 
18. Odluka o meritumu br. AP 86/05 (SG BiH br. 17/2006) u Pregled praske Ustavnog suda BiH (Drugo izdanje, Sarajevo, 2016)

19. Odluka U-21/16 USBiH (9. lipnja 2017.)

20. Odluka U-5/16 USBiH (29. lipnja 2017.)

21. Panovits $v$ Cyprus App no 4268/04 (ECtHR, 11 December 2008)

22. Presuda $030 \mathrm{~K} 00792412 \mathrm{Kž} 8 \mathrm{VSFBiH}$ (22. svibnja 2013.)

23. Presuda vijeća Apelacijskog odjeljenja br. S1 2 K 00335414 Kž 13 (19. rujna 2014) u Bilten sudske prakse $5 / 2015$

24. Rješenje 070-0-Kž-09-000449 VSFBiH (6. listopada 2009.)

25. Rješenje Izvanraspravnog vijeća Suda BiH br. S1 2 K 01920016 Kv (12. listopada 2016.) u Bilten sudske prakse 7/2017

26. Salduz $v$ Turkey App no 36391/02 (ECtHR, 27 November 2008)

27. Şaman v Turkey App no 35292/05 (ECtHR, 5 April 2011)

28. Saunders $v$ United Kingdom App no 19187/91 (ECtHR, 17 December 1996)

29. Sudska praksa br. S1 2 K 00255210 Krn (X-KRN/09/707)

30. Twalib v Greece App no 42/1997/826/1032 (ECtHR, 9 June 1998)

31. Zahtjev za ocjenu ustavnosti, br. U-5/16 od 1. srpnja 2016. 


\section{INSTRUMENTS FOR PROTECTION OF THE PROCEDURAL RIGHT OF DEFENCE IN INVESTIGATION UNDER THE LAW ON CRIMINAL PROCEDURE IN BOSNIA AND HERZEGOVINA}

\section{Summary}

With the entry into force of the Criminal Procedure Code of Bosnia and Herzegovina, the roles of the prosecutor and the court have been changed significantly compared to the earlier legislation, especially in the investigative procedure. According to the existing normative framework, the role of the court in the investigation is much more passive since at this stage of the procedure the court does not control the merits of conducting the investigation. The mixed accusatorial concept of investigation as the one existing in the criminal justice system of Bosnia and Herzegovina has led to certain restrictions on the rights of the defence in investigation. Investigation is an important stage in criminal proceedings that is conducted for evidence and data collecting necessary to decide whether to file an indictment or discontinue the proceedings, as well as for evidence that can be presented at the main hearing and upon which the judgment is rendered. It is therefore necessary to ensure that a proper and lawful investigation is conducted. This means to make sure that all parties involved in the investigation, especially defence are treated in a fair manner. The right to defence is a fundamental human and constitutional right guaranteed by international conventions. The right to defence results in several individual rights enjoyed by suspects in preliminary proceedings. In order to ensure effective judicial protection of the rights of the suspects, the paper analyses the domestic criminal justice system and presents comparative legal solutions regarding the protection of procedural rights of the defence in investigation. The fundamental issues in analysing regulatory framework in Bosnia and Herzegovina are the lack of effective judicial protection of procedural rights of the defence, the absence of an effective legal remedy to conduct an investigation facilitating the principle of a fair trial for defence and the principle of equality of arms in pre-trial proceedings. In addition, the paper analyses the issue of informing the suspect of an order for investigation, since according to applicable regulations, the suspect does not even need to know about an investigation conducted against him, which is a violation of the principle of right to a fair trial.

Keywords: $\quad$ right of defence in investigation, order for investigation, instruments for procedural rights protection of defence, effective legal remedy, judicial control of the investigation

\section{(c) (1) (9)}

This work is licensed under a Creative Commons

Attribution-NonCommercial 4.0 International License.

\footnotetext{
Maja Pilić, PhD, Assistant Professor, Faculty of Law, University of Mostar, Matice hrvatske b.b., 88000 Mostar, Bosnia and Herzegovina. E-mail address: maja.pilic@pf.sum.ba. ORCID: https://orcid.org/0000-0003-1979-3023.

** Zdravko Rajić, Attorney, Stjepana Radića 7, 88000 Mostar, Bosnia and Herzegovina. E-mail address: zdravko.rajic1@tel.net.ba. ORCID: https://orcid.org/0000-0003-2638-8974.
} 